\title{
Three manganese oxide-rich marine sediments harbor similar communities of acetate-oxidizing manganese-reducing bacteria
}

\author{
Verona Vandieken ${ }^{1,5}$, Michael Pester ${ }^{2}$, Niko Finke ${ }^{1,6}$, Jung-Ho Hyun ${ }^{3}$, \\ Michael W Friedrich ${ }^{4}$, Alexander Loy ${ }^{2}$ and Bo Thamdrup ${ }^{1}$ \\ ${ }^{1}$ Nordic Center for Earth Evolution, University of Southern Denmark, Odense, Denmark; ${ }^{2}$ Department \\ of Microbial Ecology, Faculty of Life Sciences, University of Vienna, Vienna, Austria; ${ }^{3}$ Department of \\ Environmental Marine Sciences, Hanyang University, Ansan, South Korea and ${ }^{4}$ Department of Microbial \\ Ecophysiology, University of Bremen, Bremen, Germany
}

\begin{abstract}
Dissimilatory manganese reduction dominates anaerobic carbon oxidation in marine sediments with high manganese oxide concentrations, but the microorganisms responsible for this process are largely unknown. In this study, the acetate-utilizing manganese-reducing microbiota in geographically well-separated, manganese oxide-rich sediments from Gullmar Fjord (Sweden), Skagerrak (Norway) and Ulleung Basin (Korea) were analyzed by 16S rRNA-stable isotope probing (SIP). Manganese reduction was the prevailing terminal electron-accepting process in anoxic incubations of surface sediments, and even the addition of acetate stimulated neither iron nor sulfate reduction. The three geographically distinct sediments harbored surprisingly similar communities of acetateutilizing manganese-reducing bacteria: 16S rRNA of members of the genera Colwellia and Arcobacter and of novel genera within the Oceanospirillaceae and Alteromonadales were detected in heavy RNA-SIP fractions from these three sediments. Most probable number (MPN) analysis yielded up to $10^{6}$ acetate-utilizing manganese-reducing cells $\mathrm{cm}^{-3}$ in Gullmar Fjord sediment. A $16 \mathrm{~S}$ rRNA gene clone library that was established from the highest MPN dilutions was dominated by sequences of Colwellia and Arcobacter species and members of the Oceanospirillaceae, supporting the obtained RNA-SIP results. In conclusion, these findings strongly suggest that (i) acetatedependent manganese reduction in manganese oxide-rich sediments is catalyzed by members of taxa (Arcobacter, Colwellia and Oceanospirillaceae) previously not known to possess this physiological function, (ii) similar acetate-utilizing manganese reducers thrive in geographically distinct regions and (iii) the identified manganese reducers differ greatly from the extensively explored iron reducers in marine sediments.
\end{abstract}

The ISME Journal (2012) 6, 2078-2090; doi:10.1038/ismej.2012.41; published online 10 May 2012

Subject Category: geomicrobiology and microbial contributions to geochemical cycles

Keywords: 16S rRNA-SIP; manganese reduction; marine sediment; MPN counts

\section{Introduction}

Energetically, manganese oxide is a much more favorable electron acceptor than iron oxide or sulfate. Accordingly, manganese-reducing microorganisms are expected to outcompete iron and sulfate reducers for common substrates, and microbial manganese reduction indeed dominates carbon

Correspondence: V Vandieken, Institute for Chemistry and Biology of the Marine Environment, University of Oldenburg, Carl-von-Ossietzky-Str. 9-11, 26129 Oldenburg, Germany.

E-mail: vvandieken@daad-alumni.de

${ }^{5}$ Current address: Institute for Chemistry and Biology of the Marine Environment, University of Oldenburg, Oldenburg, Germany. ${ }^{6}$ Current address: Department of Marine Sciences, University of Georgia, Athens, GA, USA.

Received 6 September 2011; revised 29 March 2012; accepted 29 March 2012; published online 10 May 2012 mineralization over iron and sulfate reduction in some marine sediments (Lovley and Goodwin, 1988; Thamdrup, 2000). Sediments where microbial manganese reduction is important have been found, for example, in the Panama Basin, deep parts of the Skagerrak, the Black Sea and the northern Barents Sea (Canfield et al., 1993a, b; Thamdrup et al., 2000; Vandieken et al., 2006b; Nickel et al., 2008). These are characterized by high manganese oxide concentrations of $25-185 \mu \mathrm{mol} \mathrm{cm}^{-3}$ to depths of 1 to $>10 \mathrm{~cm}$, and manganese reduction accounts for $25-99 \%$ of anaerobic carbon oxidation in the upper $10 \mathrm{~cm}$ of sediments. These conditions are contrasted by the generally low concentrations $\left(\leqslant 20 \mu \mathrm{mol} \mathrm{cm}{ }^{-3}\right)$ and shallow depth distribution $(\leqslant 2 \mathrm{~cm})$ of manganese oxide in most continental marine sediments (Thamdrup, 2000). High concentrations of manganese oxides are often found in the 
deepest parts of fjords or ocean basins, which are suggested to function as traps for manganese that is released from more reducing sediments into the water column and by lateral transport and later reprecipitation accumulates in more oxidized sediments (Thamdrup et al., 1994; Thamdrup, 2000).

The diversity of microbes involved in dissimilatory manganese reduction in aquatic sediments is largely unexplored. Although a large number of microorganisms capable of manganese reduction is known (Lovley et al., 2004), many of these were isolated as iron reducers from environments dominated by iron reduction and were only subsequently shown to reduce manganese oxides in culture. The few species that have been enriched and isolated with manganese oxide include Shewanella putrefaciens MR1 from marine sediment and the thermophile Bacillus infernus isolated from terrestrial subsurface (Burdige and Nealson, 1985; Myers and Nealson, 1988; Boone et al., 1995). Manganese reduction is rarely tested in the description of new species, so that this capability might be more widespread in existing isolates than is currently known. As detailed studies of manganese-reducing bacteria are missing and most iron reducers are able to reduce manganese oxides as well, we are currently restricted to using these organisms as models for understanding microbial manganese reduction in nature. Considering the large difference in redox potential between manganese and iron oxides (Thamdrup, 2000), however, it seems likely that manganese reduction in the environment is actually carried out by specialized manganese reducers.

To our knowledge, only one previous study from the Black Sea has combined the analysis of activity and identity of manganese reducers in sediments (Thamdrup et al., 2000). Interestingly, most probable number (MPN) counts of manganese reducers were three orders of magnitude higher than MPN counts of iron reducers, suggesting that different groups of microorganisms conveyed the two processes. Arcobacter- and Pelobacter-related species were identified as manganese reducers by $16 \mathrm{~S}$ rRNA gene clone library surveys of the highest MPN dilutions that showed growth. Whereas Pelobacter belongs to the order Desulfuromonadales that contains many characterized iron- and manganese-reducers, Arcobacter had not been previously recognized to be capable of reducing metal oxides.

Stable isotope probing (SIP) of nucleic acids is a cultivation-independent method that is widely applied to link utilization of an isotope-labeled (for example, ${ }^{13} \mathrm{C}$ ) substrate to the phylogenetic identity of the responsible organisms. Substrate labeled with ${ }^{13} \mathrm{C}$ is fed to, for example, sediment incubations so that the RNA and DNA of microorganisms turning over this substrate become labeled with ${ }^{13} \mathrm{C}$ and the organisms can be identified subsequently by molecular methods (Whiteley et al., 2006; Whiteley et al., 2007; Pester and Loy, 2010). Particularly in SIP incubations with only one dominating electronaccepting process, selective isotopic enrichment of nucleic acids strongly suggests that the microorganisms harboring these heavy nucleic acids are the ones that catalyze this process. With this technique, members of the order Desulfuromonadales were identified to couple dissimilatory iron reduction to the oxidation of ${ }^{13} \mathrm{C}$-acetate in a uranium-contaminated aquifer and rice field soil (Chang et al., 2005; Hori et al., 2010). Other bacteria, which became isotopically labeled by metabolizing ${ }^{13} \mathrm{C}$-labeled substrates under iron-reducing conditions, belonged to members of the class Betaproteobacteria and Gram-positive Peptococcaceae that had not before been linked to iron reduction (Kunapuli et al., 2007; Hori et al., 2010; Pilloni et al., 2011).

In this study, RNA-SIP was applied for the first time to identify manganese-reducing bacteria in three manganese oxide-rich marine sediments from Swedish, Norwegian and Korean waters where the dominance of microbial manganese reduction in carbon oxidation was previously shown or suggested (Canfield et al., 1993a, b; Engström et al., 2005; Hyun et al., 2010). As acetate is an important electron donor for microbial iron and sulfate reduction in marine sediments (Sørensen et al., 1981; Parkes et al., 1989; Fukui et al., 1997; Finke et al., 2007), we chose $\left({ }^{13} \mathrm{C}\right.$-labeled) acetate as the substrate for RNA-SIP studies and MPN counts of manganese reducers.

\section{Materials and methods}

\section{Study sites}

Manganese oxide-rich sediment was sampled at three locations: the Gullmar Fjord on the west coast of Sweden $\left(58^{\circ} 19.35 \mathrm{~N} 011^{\circ} 32.75 \mathrm{E}\right.$; Engström et al., 2005), the Norwegian Trough in Skagerrak between Denmark and Norway (58 $14.1 \mathrm{~N} 09^{\circ} 32.1 \mathrm{E}$; Canfield et al., 1993a, b) and the Ulleung Basin in the East Sea off South Korea $\left(36^{\circ} 59.811 N\right.$ 130 $59.750 E$; Hyun et al., 2010). Sampling is detailed in Supplementary Methods. Manganese oxides of surface sediment from the Skagerrak site have been shown to consist of pure Mn(IV) oxide (Canfield et al., 1993b; Thamdrup and Dalsgaard, 2000) whereas in Gullmar Fjord it was estimated to be $2 / 3 \mathrm{Mn}(\mathrm{IV})$ and $1 / 3$ Mn(II) (Goldberg et al., 2012).

\section{Sediment incubations}

Incubations were started either immediately after sampling (Ulleung Basin and Skagerrak) or for Gullmar Fjord sediment, 12 days after storing the intact cores with the overlying water being aerated. For the incubations, sediments from $0-5 \mathrm{~cm}$ depth in Gullmar Fjord and Skagerrak and from $0-2.5 \mathrm{~cm}$ in Ulleung Basin were pooled from several sediment cores, mixed with anoxic site water (3:1 sediment: site water w/w for Gullmar Fjord and Skagerrak, 
and 1:1 for Ulleung Basin) and homogenized. Three sediment slurries were prepared for each field site and transferred under $\mathrm{N}_{2}$ into glass bottles that were closed with thick butyl stoppers, flushed with $\mathrm{N}_{2}$ and incubated anoxically at $6{ }^{\circ} \mathrm{C}$ in the dark for 13 days (Gullmar Fjord and Ulleung Basin) or 8 days (Skagerrak). For each experiment, two of the slurries were amended every day (except for day 5, 11 and 12 for the Gullmar Fjord incubations) with $\sim 170 \mu \mathrm{M}$ (final concentration) of either unlabeled $\left({ }^{12} \mathrm{C}-\right)$ or $\left(\mathrm{U}-{ }^{13} \mathrm{C}\right)$-labeled acetate. The third slurry was incubated as a control without acetate addition. During the incubations, slurries were subsampled for porewater and solid phase analyses, RNA/DNA extractions and sulfate reduction rate measurements just before each addition of acetate (described in detail in Supplementary Methods). After subsampling, the headspace was flushed with $\mathrm{N}_{2}$.

\section{MPN counts and DNA extraction}

MPN counts of manganese reducers were conducted with Gullmar Fjord sediment with six different electron donors and manganese oxides as electron acceptor (for details see Supplementary Methods). Hungate tubes were incubated for 18 months at $15^{\circ} \mathrm{C}$ and activity was indicated by the complete disappearance of brown manganese oxide. From the highest active dilution of acetate-oxidizing cultures, DNA was extracted, amplified and cloned as described in Supplementary Methods.

\section{RNA/DNA extraction and density gradient centrifugation}

RNA and DNA were co-extracted from $\sim 1 \mathrm{~g}$ frozen sediment $\left(-80^{\circ} \mathrm{C}\right)$ from different sampling days (day 0, 2 and 6 for Gullmar Fjord; day 0 and 7 for Ulleung Basin; and day 0 and 6 for Skagerrak sediments) of the three treatments with the PowerSoil Total RNA Isolation Kit in combination with the DNA Elution Accessory Kit (MoBio, Carlsbad, CA, USA). The RNA was further purified with a Qiagen (Hilden, Germany) AllPrep DNA/RNA Mini Kit and quantified with Ribogreen RNA-quantification kit (Invitrogen, Eugene, OR, USA). Portions of $530 \mathrm{ng}$ total RNA were separated by density gradient ultracentrifugation and the gradients were fractionated and further processed as described by Whiteley et al. (2007). The concentration of RNA in each fraction was determined using Ribogreenbased fluorimetry (Invitrogen). Terminal restriction fragment length polymorphism (T-RFLP) analysis, cloning and phylogenetic analyses of 16S rRNA genes are detailed in Supplementary Methods.

\section{Nucleic acid sequences}

The sequence data have been submitted to the GenBank database under accession Nos. JN621327JN621401 (Gullmar Fjord, day 0), JN621402-JN621479 (Ulleung Basin, day 0), JN621480-JN621560
(Skagerrak, day 0), JN621561-JN621649 (Gullmar Fjord, heavy SIP fraction), JN621650-JN621713 (Ulleung Basin, heavy SIP fraction), JN621714JN621756 (Skagerrak, heavy SIP fraction) and JN621757-JN621780 (MPN counts, Gullmar Fjord).

\section{Results and discussion}

\section{Microbial manganese reduction during sediment} incubations

Sediments from Gullmar Fjord and Ulleung Basin were chosen because of their high concentration of manganese oxide (Engström et al., 2005; Hyun et al., 2010), which has been found to favor microbial manganese reduction at other locations (Canfield et al., 1993a, b; Thamdrup, 2000; Thamdrup et al., 2000; Vandieken et al., 2006b; Nickel et al., 2008). For the Skagerrak station, dissimilatory manganese reduction was repeatedly observed to be the principal anaerobic electron-accepting process in the upper $10 \mathrm{~cm}$ of sediment (Canfield et al., 1993a, b; Thamdrup and Dalsgaard, 2000).

For each of the three sediments, parallel incubations with labeled and unlabeled acetate showed very similar developments with respect to the measured biogeochemical parameters during the 8-13 days of incubation (Figures 1, 2 and 3 ). Dissolved inorganic carbon (DIC) concentrations corrected for $\mathrm{CaCO}_{3}$ precipitation increased in most slurries except for the control incubations without acetate addition from Ulleung Basin and Skagerrak, where DIC concentrations decreased or only increased initially (Figure 1). The precipitation of $\mathrm{CaCO}_{3}$, a characteristic of sediment incubations dominated by manganese reduction (Thamdrup et al., 2000), was observed in most slurries (data not shown). The decrease in DIC concentration after the $\mathrm{CaCO}_{3}$ correction in Ulleung Basin and Skagerrak controls was likely due to the precipitation of $\mathrm{MnCO}_{3}$, which cannot be quantified because of simultaneous production of $\mathrm{Mn}^{2+}$ by manganese reduction (Thamdrup et al., 2000). Thus, carbon oxidation rates might be underestimated (Thamdrup et al., 2000).

Manganese oxide concentrations ranged from 38 to $95 \mu \mathrm{mol} \mathrm{cm}^{-3}$ (Table 1), which is high enough to expect manganese reduction to dominate anaerobic carbon oxidation completely (Thamdrup, 2000). Manganese reduction was indicated directly by the accumulation of dissolved $\mathrm{Mn}^{2+}$ during the incubations from Gullmar Fjord and Ulleung Basin, and accumulation rates increased substantially with acetate amendment, suggesting that the process was limited by organic carbon (Figure 2). The rate of $\mathrm{Mn}^{2+}$ accumulation strongly underestimates the rate of manganese reduction in manganese oxiderich sediments owing to the strong adsorption of $\mathrm{Mn}^{2+}$ to manganese and iron oxide surfaces as well as potential precipitation of $\mathrm{MnCO}_{3}$ (Canfield et al., 1993a, Thamdrup et al., 2000). Such strong adsorption likely explains the lag phase in $\mathrm{Mn}^{2+}$ 

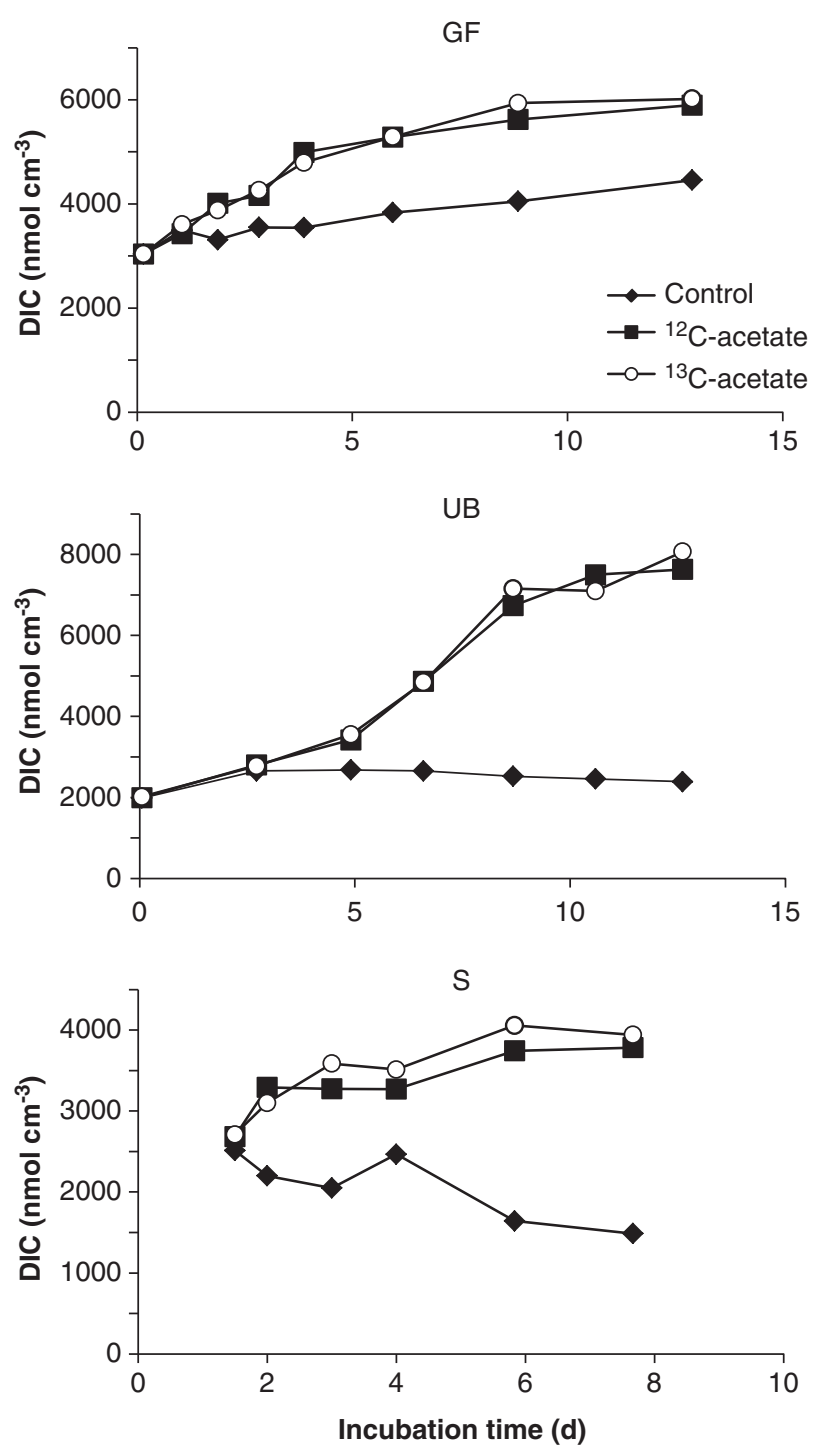

Figure 1 DIC concentration corrected for $\mathrm{CaCO}_{3}$ precipitation during incubations of Gullmar Fjord (GF), Ulleung Basin (UB) and Skagerrak (S) sediments.

accumulation in the Ulleung Basin experiment as well as the total lack of accumulation in the Skagerrak sediment, which had the highest manganese oxide content. Very low rates of $\mathrm{Mn}^{2+}$ accumulation were previously reported for the most manganese oxide-rich part of this sediment (Thamdrup and Dalsgaard, 2000).

$\mathrm{Fe}^{2+}$ and sulfide concentrations in the porewater stayed below the detection limit throughout the incubations with and without acetate amendment (sulfide was not measured for Skagerrak incubations) and sulfate reduction rates were either very low $\left(\leqslant 3.1 \mathrm{nmol} \mathrm{cm}^{-3} \mathrm{~d}^{-1}\right)$ or below detection throughout all the incubations of Gullmar Fjord and Ulleung Basin sediments. Sulfate reduction was not measured in the Skagerrak sediment but the process has previously been shown to be unimportant there (Canfield et al., 1993a, b; Thamdrup and Dalsgaard, 2000).
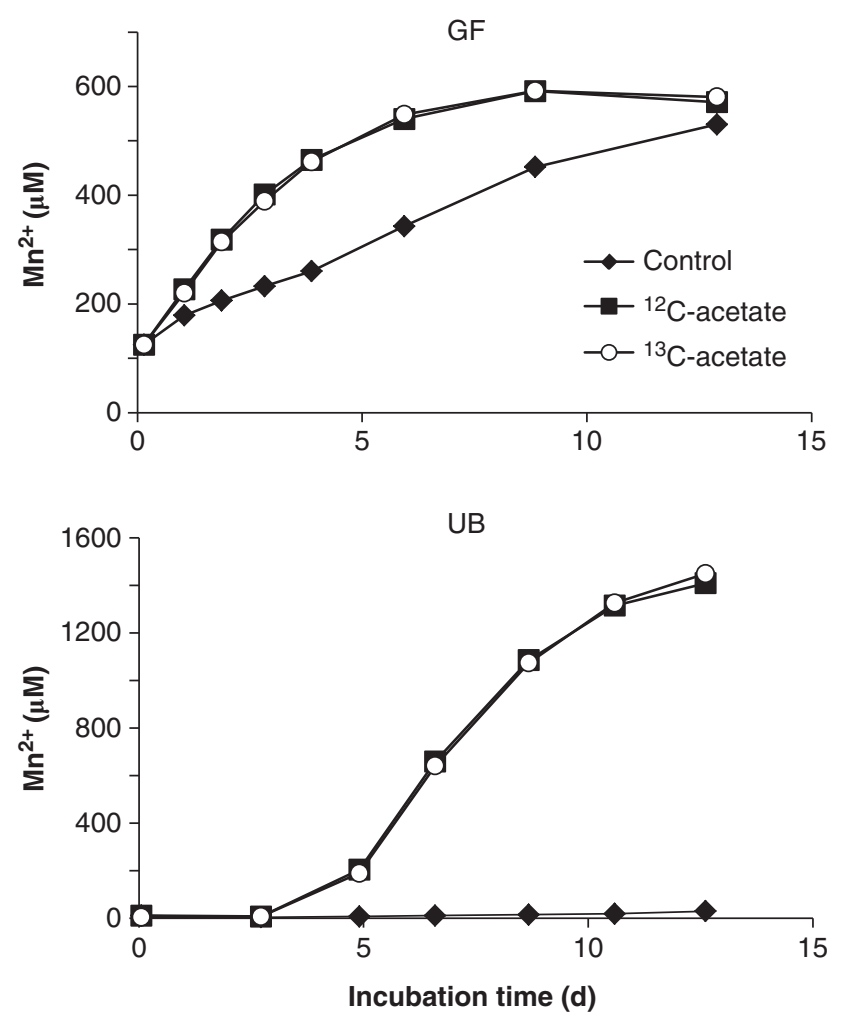

Figure 2 Porewater $\mathrm{Mn}^{2+}$ concentrations during incubations of $\mathrm{GF}$ and UB sediments. $\mathrm{Mn}^{2+}$ concentrations in all three $\mathrm{S}$ incubations stayed $<5 \mu \mathrm{M}$.
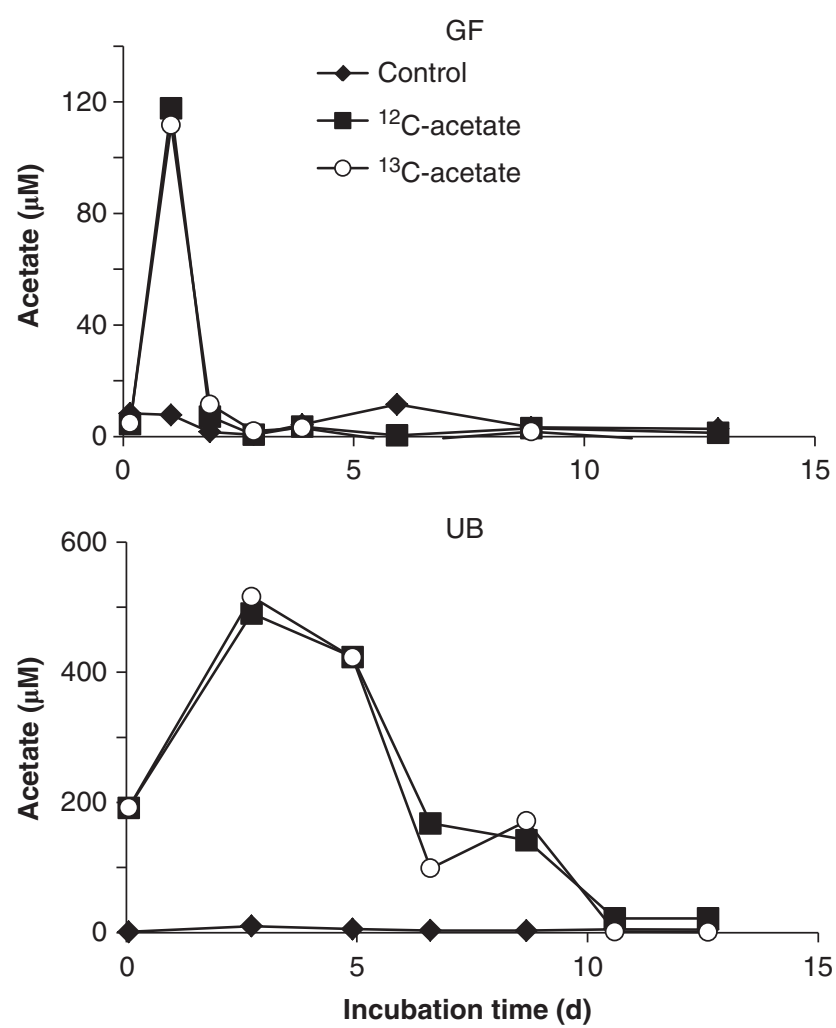

Figure 3 Acetate concentrations during incubations of the GF and UB sediments. Acetate concentrations during the $\mathrm{S}$ sediment incubations were not measured. 
Table 1 Manganese and iron concentrations $\left(\mu \mathrm{mol} \mathrm{cm}{ }^{-3}\right)$ at the beginning of the incubations

\begin{tabular}{lccc}
\hline Sediment & Total Mn & Total Fe & Fe(III) \\
\hline Gullmar Fjord & 37.9 & 49.7 & 45.8 \\
Ulleung Basin & 40.2 & 17.8 & 15.0 \\
Skagerrak & 94.5 & 53.2 & 52.9 \\
\hline
\end{tabular}

As discussed in earlier studies (Canfield et al., 1993a, b; Thamdrup, 2000), reduction of iron or sulfate could be masked by rapid reoxidation with manganese oxide, but manganese-reducing bacteria are expected to outcompete iron and sulfate reducers when manganese oxide is abundant (Lovley and Goodwin, 1988), and previous experiments with molybdate inhibiting sulfate reduction and ferrozine as a scavenger for $\mathrm{Fe}^{2+}$ showed no sign of such reactions (Canfield et al., 1993b). Supporting these findings, our RNA-SIP results identified no known taxa of sulfate-reducing bacteria (see below, Table 2). Thus, based on our results and previous studies, we conclude that manganese reduction was the dominating electron-accepting process during the incubations of the three sediments from Gullmar Fjord, Ulleung Basin and Skagerrak, with minimal contribution of sulfate reduction to anaerobic carbon oxidation $(<2 \%$ for Gullmar Fjord and Ulleung Basin incubations; assuming a stoichiometry of 2:1 for DIC produced to sulfate reduced (Thamdrup and Canfield, 1996)).

Acetate oxidation during the sediment incubations Control incubations of Gullmar Fjord and Ulleung Basin sediments that were not amended with acetate showed acetate concentrations $<12 \mu \mathrm{M}$ throughout the duration of the experiments (Figure 3) (not measured for Skagerrak incubations), which is at the lower end of reported concentrations for marine sediments (Sansone and Martens, 1982; Fukui et al., 1997; Wellsbury et al., 2002; Finke et al., 2007; Heuer et al., 2009). Acetate has been shown previously to be the most important volatile fatty acid in terms of concentration and turnover, and identified as important substrate for anaerobic terminal electron-accepting processes in marine sediments (Sørensen et al., 1981; Parkes et al., 1989; Fukui et al., 1997; Finke et al., 2007). The addition of $170 \mu \mathrm{m}$ acetate per day to our incubations exceeded these low concentrations of acetate in the control without acetate and stimulated its mineralization (Figures 1 and 3). Transient accumulation of acetate at the beginning of the acetate-amended incubations showed that the microbial community in Gullmar Fjord and Ulleung Basin sediments (not tested for Skagerrak) needed time to adjust to elevated acetate concentrations (Figure 3). However, already after the second addition, the microbial community from Gullmar Fjord was able to oxidize the added acetate and bring the concentration to the level of the control within 1 day. In the Ulleung
Basin incubations, transient acetate accumulation to a maximum of $500 \mu \mathrm{M}$ lasted longer but started to decrease again at day 3 with concentrations similar to the control being reached after 11 days (Figure 3).

In all three sediments, DIC production was significantly stimulated by the addition of acetate compared with the controls without acetate addition (Figure 1). For Gullmar Fjord sediment, the total anaerobic carbon oxidation rates in the incubations with acetate amendment were threefold higher than in the control (Figure 1). The potential DIC production from the oxidation of all added acetate accounted for $108 \%, 74 \%$ and $73 \%$, respectively, of the measured increase in DIC production for Gullmar Fjord, Ulleung Basin and Skagerrak. Thus, acetate oxidation must have dominated DIC production in the incubations with acetate amendment. Addition of acetate should relieve the competition between manganese and sulfate reducers at least in Ulleung Basin sediments, where acetate accumulated in the pore water (Figure 3) (Achtnich et al., 1995). Thus, the absence of sulfate reduction must be explained by a small population of acetateoxidizing sulfate reducers in surface sediments or by inhibition by unknown factors.

\section{Bacterial community composition in the three} manganese oxide-rich sediments

Bacterial 16S rRNA gene clone libraries of the geographically distinct sediments at day 0 revealed a diverse benthic community for all three sediments (Supplementary Table 1, Supplementary Figure 1). Already at the approximated family level $(\geqslant 90 \% 16 \mathrm{~S}$ rRNA gene sequence similarity), the three surface sediment bacterial communities were highly dissimilar (0.77-0.82 Bray-Curtis dissimilarity, Supplementary Table 2). This was corroborated by T-RFLP fingerprinting analyses with little overlap between major terminal restriction fragments (T-RFs), especially between the Ulleung Basin and the geographically closer situated Gullmar Fjord and Skagerrak sediments (Supplementary Figure 2). Combined analysis of the clone libraries and T-RFLP profiles indicated that the only major ubiquitously found microbial taxa in all three sediments belonged to the Sinobacteraceae and/or Chromatiaceae (based on a T-RF calling accuracy of \pm 1 base pair) (Supplementary Table 1, Supplementary Figure 2), with both families belonging to the Gammaproteobacteria. Major similarities in community composition became only apparent at higher taxonomic levels and comprised Alpha-, Gamma- and Deltaproteobacteria, as well as Planctomycetes and Acidobacteria (Supplementary Figure 1).

\section{Acetate-oxidizing bacteria identified by SIP of $16 S$ rRNA}

The bacterial community composition did not seem to change markedly throughout the incubations from any of the stations, as no major changes in 
Table 2 Phylogenetic affiliation and relative abundance of bacterial 16S rRNA sequences obtained from clone libraries of heavy SIP fractions of the Gullmar Fjord (GF), Ulleung Basin (UB) and Skagerrak (S) sediments as well as from most probable number (MPN) counts of GF sediment

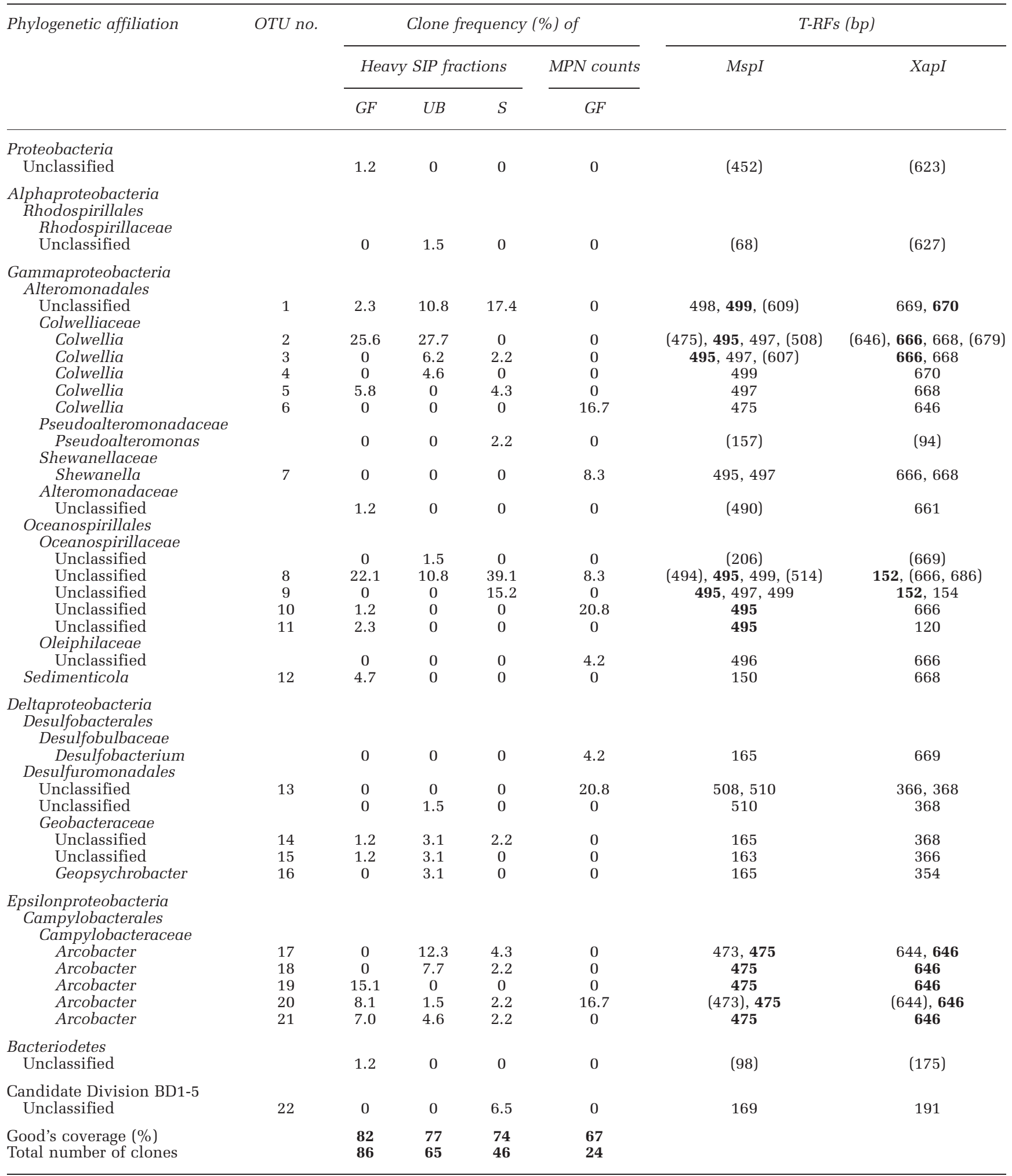

Phylogenetic information is resolved to the approximate genus level ( $\geqslant 95 \% 16 \mathrm{~S}$ rRNA sequence identity). Multiple mentioning of the same taxon represent sequences $>95 \%$ sequence similarity. Lengths of T-RFs are given for restriction digests with the enzymes MspI and XapI. Multiple T-RFs represent different restriction sites of different sequences (determined in silico from clone sequences). T-RFs in parenthesis were only recognized for one sequence and T-RFs in bold can be found in T-RFLP profiles of heavy SIP fractions (Figure 4, Supplementary Figure 4). The phylogenetic position of OTUs is illustrated in Figure 5. Clone frequencies of $1.2 \%, 1.5 \%, 2.2 \%$ and $4.2 \%$ represent one clone sequence for GF, UB, S and MPN counts clone libraries, respectively. 


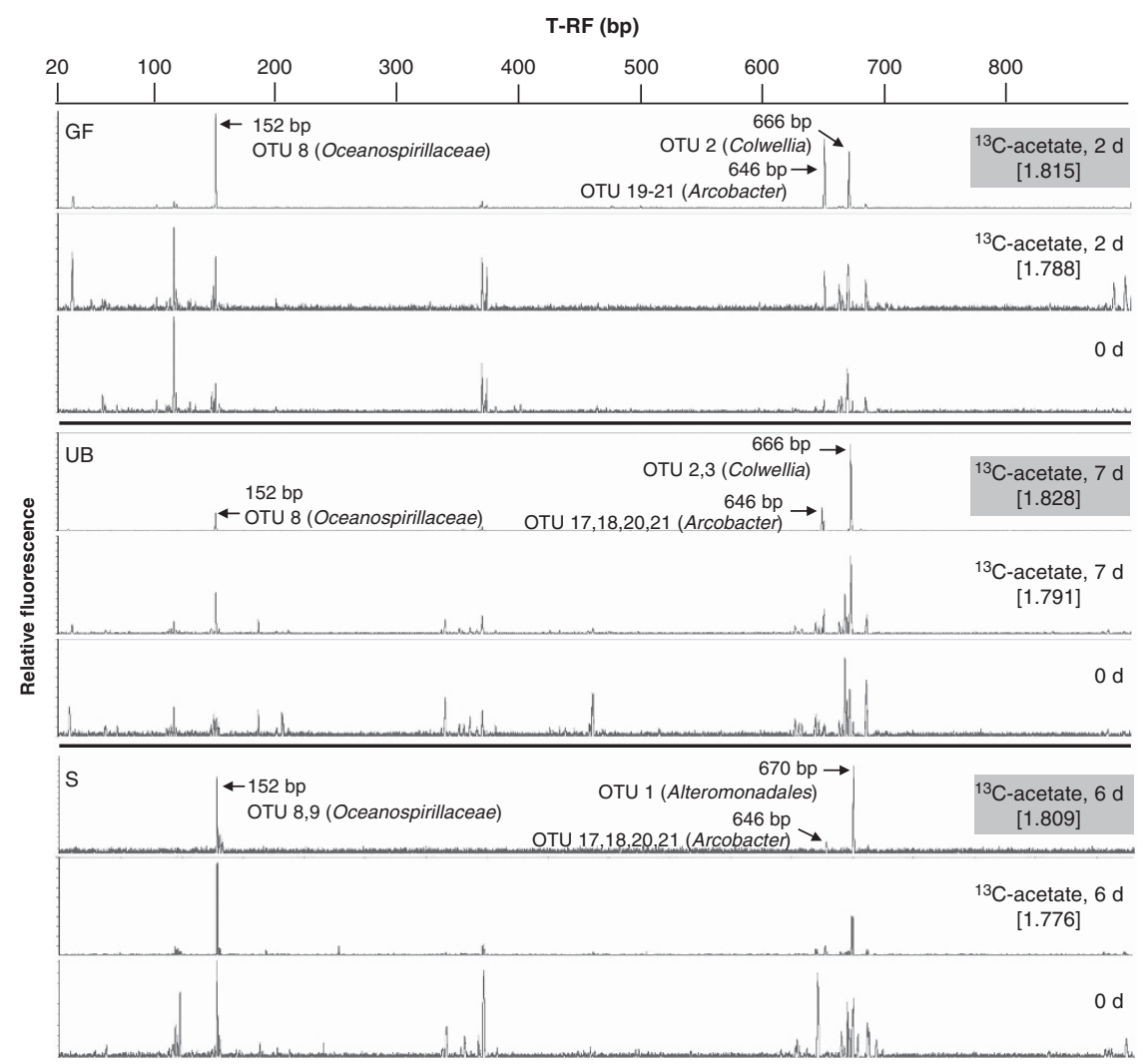

Figure 4 T-RFLP analysis (XapI) of 16S rRNA-complimentary DNA amplicons obtained from one selected heavy and light RNA fraction of incubations with ${ }^{13} \mathrm{C}$-acetate of GF, UB and S sediments in comparison with the original sediment at day 0. Representing 16S rRNAcomplimentary DNA clones of major T-RFs can be found in Table 2 and a differential T-RFLP analysis (MspI) of heavy and light fractions in Supplementary Figure 4. Numbers in parentheses represent the density of fractions in $\mathrm{g} \mathrm{ml}^{-1}$, heavy fractions $\left(\geqslant 1.80 \mathrm{mgl}^{-1}\right)$ are marked by gray background.

community fingerprints were detected in $16 \mathrm{~S}$ rRNA gene-based T-RFLP analyses (Supplementary Figure 2). Minor increases in T-RF abundances were observed for T-RFs at 475 base pairs for Gullmar Fjord and at 495 base pairs for Skagerrak in acetateamended incubations. As T-RFLP patterns of controls without acetate did not change, this might point to growth initiation of represented bacteria triggered by the addition of acetate.

Isopycnic RNA centrifugation of selected time points within the first 7 days of incubation revealed significant amounts of ${ }^{13} \mathrm{C}$-labeled $\mathrm{RNA}$ in heavy SIP-fractions of ${ }^{13} \mathrm{C}$-acetate incubations (>1.80 $\mathrm{g} \mathrm{ml}^{-1}$, Lueders et al., 2004), which was corroborated by comparison with heavy fractions of the incubations with ${ }^{12} \mathrm{C}$-acetate and without acetate (Supplementary Figure 3). Successful labeling was also supported by a general absence of reverse transcriptase-PCR products of bacterial 16S rRNA from the heavy SIP-fractions of ${ }^{12} \mathrm{C}$-acetate and the non-amended control incubations after 19-22 PCR cycles (Supplementary Figure 4 and data not shown, respectively).

Bacterial 16S rRNA resolved within the centrifugation gradients were initially analyzed by T-RFLP fingerprinting, using the restriction enzyme MspI.
In all three sediments, T-RFLP profiles obtained from heavy RNA-SIP fractions of the ${ }^{13} \mathrm{C}$-acetate incubations showed a much lower diversity compared with light fractions and the original bacterial community at the beginning of the incubations (Supplementary Figure 4). This clearly indicates that only a few bacterial groups oxidized the added ${ }^{13} \mathrm{C}$-acetate and concomitantly incorporated ${ }^{13} \mathrm{C}$ into their RNA. In the ${ }^{13} \mathrm{C}$-acetate incubations, T-RFLP profiles $(M s p \mathrm{I}$ digest) of the heavy SIP fractions were dominated by two to three major T-RFs for all three sediments (Supplementary Figure 4); and a differential T-RFLP analysis with the restriction enzyme XapI indicated label incorporation by bacteria represented by three different T-RFs for each sediment (Figure 4).

Clone libraries of reversely transcribed bacterial 16S rRNA from heavy fractions of ${ }^{13} \mathrm{C}$-acetate incubations were dominated by four groups for all three sediments (Table 2). In combination with the T-RFLP analyses, these groups were regarded as active acetate-oxidizing manganese reducers and were affiliated to the genera Colwellia (Colwelliaceae, Gammaproteobacteria, operational taxonomic unit (OTU) 2-5) and Arcobacter (Campylobacteraceae, Epsilonproteobacteria, OTU 17-21) as well as to new genera within the Oceanospirillaceae 


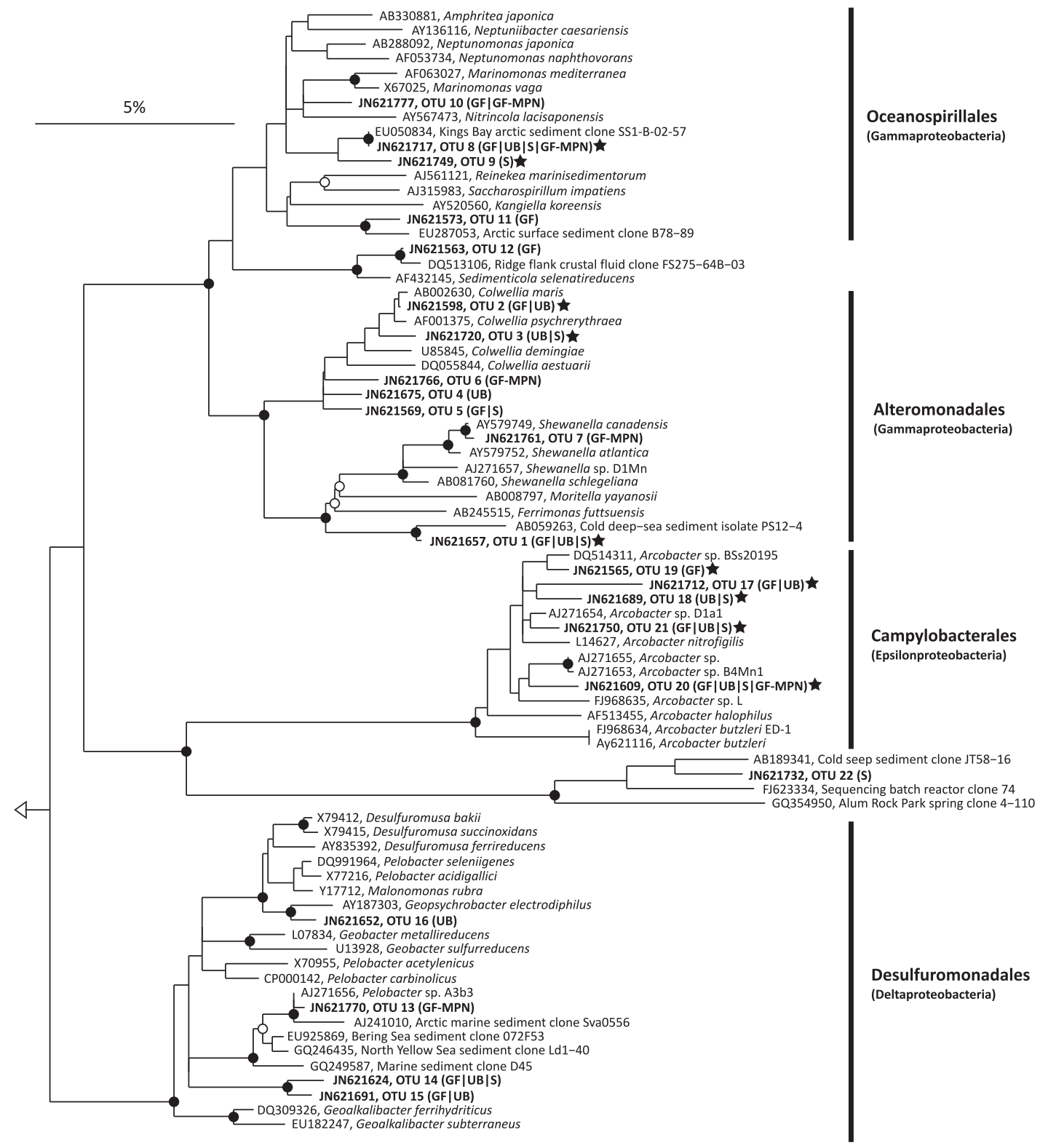

Candidate Phylum BD1-5

Figure 5 16S rRNA consensus tree showing the affiliation of OTUs detected in heavy SIP fractions of ${ }^{13} \mathrm{C}$-actetate incubations of GF, UB and S sediments and in acetate-oxidizing manganese-reducing MPN cultures of GF sediment (GF-MPN). Sequences of Pelobacter sp. A3Mn2, Arcobacter sp. B4Mn1 and Shewanella strain D1Mn were clone sequences of manganese-reducing MPN counts of Black Sea sediment taken from Thamdrup et al. (2000). Arcobacter-L and Arcobacter ED1 sequences stem from acetate-fed microbial fuel cells of Fedorovich et al. (2009). Stars indicate OTUs for which ${ }^{13} \mathrm{C}$-label incorporation was confirmed by comparative T-RFLP analysis of light and heavy SIP fractions (Figure 4, Supplementary Figure 4). OTUs that were represented by only one clone sequence are not shown. Relative abundance of OTUs is indicated in Table 2. Filled and open circles indicate lineages with $>90 \%$ and $75-90 \%$ maximum likelihood bootstrap support, respectively. Aquifex pyrophilus (M83548) was used as outgroup. The scale bar indicates 5\% estimated sequence divergence.

(Gammaproteobacteria, OTU 8-11) and Alteromonadales (Gammaproteobacteria, OTU 1), accounting for $26 \%, 23 \% 31 \%$ and $10 \%$ of the clones, respectively, as an average for all stations (Table 2, Figure 5). Out of these four groups, the acetateoxidizing manganese reducers identified by the combination of all three approaches (clone library and T-RFLP analyses with both restriction enzymes) were the bacteria affiliated to Arcobacter (OTU 18-22) and Oceanospirillaceae (OTU 8-11) for all three sediments whereas bacteria affiliated to Colwellia (OTU 2-3) were identified only in the Gullmar Fjord and Ulleung Basin sediments and bacteria affiliated to Alteromonadales (OTU 1) in the Skagerrak sediment (Figures 4 and 5, Supplementary Figure 4). In support of our biogeochemical analyses, we did not find sequences related to known sulfate-reducing bacteria in clone libraries of heavy 
fractions (Table 2). This result corroborates our conclusion that sulfate reduction was of no importance for acetate oxidation during the incubations.

Interestingly, sequences similar to the four groups of active manganese reducers (same affiliation and same MspI/XapI restriction site) in clone libraries of the original sediments were only detected within the Oceanospirillaceae for Gullmar Fjord and Skagerrak, and for Alteromonadales for Ulleung Basin and Skagerrak (Supplementary Table 1). Although the coverage of the original sediment clone libraries were only between $39 \%$ and $62 \%$ (on 90\% sequence identity level) (Supplementary Table 1) and, thus, sequences of the identified acetate-reducing manganese reducers might have been missed in the original samples, it is also possible that other electron donors, possibly of greater importance than acetate, were used by different groups of manganese reducers in situ. Thus, only a subset of the manganese-reducing communities in the three sediments would have been identified by SIP.

\section{Manganese reducers in MPN counts of Gullmar Fjord} sediment

Growth of manganese-reducing microorganisms was obtained with all tested electron donors (acetate, lactate, propionate, ethanol, butyrate and formate) in MPN counts of Gullmar Fjord sediment with the highest cell numbers on lactate $\left(43 \times 10^{5} \mathrm{cells} \mathrm{cm}^{-3}\right)$ (Table 3). MPN counts of acetate oxidizers $(9.3 \times$ $10^{5}$ cells $\mathrm{cm}^{-3}$ ) were similar to cell counts (up to 5 and $1.1 \times 10^{5}$ cells $\mathrm{cm}^{-3}$, respectively) of two studies by Nealson et al. (1991) and Thamdrup et al. (2000) with manganese oxide-rich sediments of the Black Sea.

Interestingly, a bacterial 16S rRNA gene clone library constructed from the highest active MPN dilutions with acetate as substrate revealed that the majority of sequences were affiliated to the genera Colwellia, Arcobacter and Shewanella as well as new genera within the order Desulfuromonadales and the family Oceanospirillaceae (Table 2). In a similar study with Black Sea sediment clone libraries from the highest dilution of the acetateoxidizing manganese reducers revealed 16S rRNA gene sequences related to Arcobacter and Pelobacter within the Desulfuromonadales and additional, after subcultivation on lactate, to Shewanella

Table 3 Most probable number (MPN) counts $\left(10^{5}\right.$ cells $\left.\mathrm{cm}^{-3}\right)$ of manganese-reducing microorganisms in surface sediment of Gullmar Fjord

\begin{tabular}{lcc}
\hline Electron donor & MPN counts & 95\% confidence interval \\
\hline Lactate & 43 & $9-180$ \\
Acetate & 9.3 & $1.8-42$ \\
Propionate & 7.5 & $1.7-20$ \\
Ethanol & 1.5 & $0.37-4.2$ \\
Butyrate & 0.93 & $0.18-4.2$ \\
Formate & 0.75 & $0.17-2$ \\
\hline
\end{tabular}

(Thamdrup et al., 2000), which were related to the sequences of this study (90 to $>97 \%$ sequences identity to the respective sequences) (Figure 5). Shewanella and members of the Desulfuromonadales are two groups with the ability to reduce iron and manganese, which are recovered frequently through cultivation for example, with iron oxides as electron acceptor or acetate as electron donor (Caccavo et al., 1992; Venkateswaran et al., 1998; Snoeyenbos-West et al., 2000; Holmes et al., 2002; Vandieken et al., 2006a). S. putrefaciens is one of the few strains isolated directly by manganese oxide reduction (Myers and Nealson, 1988; Nealson et al., 1991). However, sequences have been rarely detected in clone libraries from marine sediments, just as in our study, and the in situ-importance of this group remains unclear (Lovley et al., 2004). This might indicate that the high substrate concentrations of cultivation-dependent methods favor organisms that are able to grow fast but might not be abundant in high numbers and/or active in the environment. Similar problems may arise for SIP experiment as fast growing organisms (like it is indicated for Arcobacter species in this and other studies (for example, Webster et al., 2010)) that would dominate an enrichment culture also become first ${ }^{13} \mathrm{C}$-labeled, although added acetate concentrations for the SIP incubations were lower than in the MPN counts. However, our combined results of cultivation-independent and cultivation-dependent methods together with the results of Thamdrup et al. (2000) give strong evidence that the taxa Arcobacter, Colwellia and Oceanospirillaceae include organisms that are capable of growing on acetate and manganese oxide and are present in distinct manganeseoxide rich sediments.

\section{Relevance of manganese reduction for the identified acetate oxidizers}

Among the taxa identified with SIP and MPN enrichments, only members of the Alteromonadales and Desulfuromonadales have been linked previously to the reduction of manganese and iron oxides in pure culture (Lovley et al., 2004). Sequences of OTU 1 within the Alteromonadales were related to cultured species of the genera Ferrimonas and Shewanella (Figure 5), in which $F$. balearica, F. kyonanensis and F. futtsuensis, as well as many Shewanella species are able to reduce iron and manganese oxides in pure culture (RossellóMora et al., 1995; Lovley et al., 2004; Nakagawa et al., 2006). All members of the Desulfuromonadales are able to reduce iron and manganese oxides (Lovley et al., 2004) and are also frequently found in clone libraries of marine sediments (for example, Ravenschlag et al., 1999; Bowman and McCuaig, 2003; Mußmann et al., 2005). Desulfuromonadalesrelated organisms can be easily enriched in sediments or microbial fuel cells by acetate addition (Snoeyenbos-West et al., 2000; Bond et al., 2002; 
Holmes et al., 2002; Holmes et al., 2004; Vandieken et al., 2006a) but have also been identified as ironreducing bacteria by cultivation-independent SIP studies with ${ }^{13} \mathrm{C}$-acetate in rice field soil and uranium-contaminated aquifer (Chang et al., 2005; Hori et al., 2010). Our finding of Desulfuromonadales in MPN enrichments coincided with their detection in clone libraries of heavy SIP fractions. However, their low abundance in clone libraries of the SIP experiments (2-11\%, Table 2) and absence of prominent T-RFs representing these microorganisms suggests that they contributed less to acetate turnover than other bacteria.

Bacteria affiliated to Colwellia, Oceanospirillaceae and Arcobacter were identified as important manganese reducers in acetate-fed SIP incubations of all three sediments. This is astonishing because metal reduction has not yet been shown in pure culture studies of members of any of these taxa. Sequences of Oceanospirillaceae and Colwellia are frequently recovered in molecular studies of marine waters and sea ice (DeLong et al., 1993; Gosink and Staley, 1995; Bowman et al., 1997; Brown and Bowman, 2001; Koskinen et al., 2011). One additional report is from a sediment (Borin et al., 2009), but judging from the eutrophic coastal setting, manganese reduction is not likely to be important there either. Isolates of these two gammaproteobacterial taxa are mainly of marine origin (Deming et al., 1988; Gosink and Staley, 1995; Bowman et al., 1998; Yumoto et al., 1998; Hedlund et al., 1999; Nogi et al., 2004; Jung et al., 2006). Most isolates are facultative anaerobes, some are able to use acetate as sole carbon and energy source and to reduce nitrate. However, in most of these studies manganese and iron reduction was not tested so that manganese reduction might be a potential metabolism for these organisms. Only four Colwellia species have been tested negative for iron reduction with acetate (Bowman et al., 1998).

In contrast to Colwellia species and members of the Oceanospirillaceae, indication for the involvement of Arcobacter species in manganese reduction stems from MPN enrichments of manganese oxiderich Black Sea sediments, as discussed above (Thamdrup et al., 2000). Arcobacter species have also been found in other sediments, with a depth distribution that could match that of manganese reduction. Manganese oxides are typically restricted to the upper one to few $\mathrm{cm}$ in coastal sediments (Aller, 1980; Sundby et al., 1981; Thamdrup et al., 1994), and fluorescence in situ hybridization counts showed high abundance of Arcobacter in surface sediment of the Wadden Sea whereas they were virtually absent below $3 \mathrm{~cm}$ depth (Llobet-Brossa et al., 1998). Similarly, $16 \mathrm{~S}$ rRNA gene sequences related to Arcobacter were only retrieved from Antarctic shelf surface sediment $(0-0.4 \mathrm{~cm})$ but not from deeper layers (Bowman and McCuaig, 2003). However, isolates of Arcobacter were obtained from both surface and deeper sediment layers of the
Wadden Sea (Freese et al., 2008). Recently, Arcobacter strains were isolated from the graphite electrode of a microbial fuel cell inoculated with marine sediment and fed with acetate (Fedorovich et al., 2009) (Figure 5), indicating that Arcobacter species are able to use acetate and transfer electrons onto solid-phase electron acceptors. In a recent cultivation-independent SIP study with estuarine sediment, Arcobacter-related bacteria incorporated ${ }^{13} \mathrm{C}$ into their DNA from acetate and glucose under various terminal electron acceptor conditions (aerobic, nitrate-, sulfate-reducing, methanogenic) (Osaka et al., 2006; Webster et al., 2010). Under sulfatereducing conditions with ${ }^{13} \mathrm{C}$-labeled acetate, Arcobacter became enriched fast and although the authors suggested that Arcobacter was involved in sulfur cycling, iron and manganese reduction during the sediment incubations were indicated by increasing concentrations of dissolved manganese and iron (Webster et al., 2010). Arcobacter-related sequences have been found in clone libraries of many marine and terrestrial habitats (Campbell et al., 2006), for example, Arctic and Antarctic surface sediments and the anoxic water column of the Cariaco Basin, the Black Sea, the African shelf and an anoxic fjord (Nitinat Lake) (Madrid et al., 2001; Bowman and McCuaig, 2003; Vetriani et al., 2003; Lavik et al., 2009; Schmidtova et al., 2009). The metabolism of these organisms in the anoxic water columns is somewhat uncertain but sulfide oxidation has been repeatedly suggested (Lin et al., 2006). Thus, the genus Arcobacter appears highly versatile and is found under many different environmental conditions though the physiology of most of its members remains unclear.

\section{Conclusions}

This study shows that microbial manganese reduction completely dominates anaerobic carbon oxidation in the surface of the three studied sediments similar to other sites with high manganese oxide concentrations (Aller, 1990; Thamdrup et al., 2000; Vandieken et al., 2006b; Nickel et al., 2008). However, manganese-reducing microorganisms have been rarely studied and directly isolated on manganese oxides, and most properties of iron reducers and iron-reducing communities have been assumed also to apply to manganese reducers. Our results of cultivation-independent SIP experiments and cultivation-based MPN counts identified Arcobacter-, Colwellia- and Oceanospirillaceae-affiliated bacteria as the main acetate-oxidizing manganese reducers. Thus, this study gives strong evidence that dissimilatory manganese reduction in the environment is conveyed by a different assemblage of bacteria than the extensively explored iron reducers, and suggests a new function for bacteria affiliated to Arcobacter, Colwellia and Oceanospirillaceae, namely the reduction of manganese oxides. 
The finding of highly similar populations of manganese reducers in all three manganese oxiderich sediments is intriguing as the locations, a Swedish fjord, the deep Skagerrak and a continental basin in the northwest Pacific, are distinct in terms of geographical distance and environmental conditions. This further leads to the conclusion that species of Arcobacter, Colwellia and new genera within the Oceanospirillaceae and Alteromonadales represent globally distributed marine bacteria, which contribute to dissimilatory manganese reduction in manganese oxide-rich sediments. As most of the groups have not been associated with iron reduction but rather metabolisms of higher energy gain (aerobic respiration and nitrate reduction), this raises fundamental questions, such as whether the mechanisms involved in extracellular electron transfer are similar to those used by iron reducers and whether the substrate spectrum of manganese reducers is as restricted as that of iron reducers, or more diverse as for aerobes.

\section{Acknowledgements}

We thank Gosia Sniady for help with the Skagerrak experiment and Trine Gregersen for help with sampling at Gullmar Fjord. We thank Tim Ferdelman and Marcel Kuypers at the Max Planck Institute for Marine Microbiology in Bremen that we could measure VFA on their high-performance liquid chromatography. We are grateful to Norbert Bittner for the help with SIP. We also thank the captains and crews of the research vessels R/V Skagerak, R/V Oscar von Sydow and R/V Onnuri. VV had been financed by a PostDoc fellowship of the Danish Natural Science Research Councils (FNU) and NF by a Marie Curie Outgoing International Fellowship. MP and AL were supported by the Austrian Science Fund (projects P23117 and P20185-B17, respectively). J-HH was supported by the Long-Term Marine Ecological Research program of Korean Ministry of Land, Transport and Maritime Affairs.

\section{References}

Achtnich C, Bak F, Conrad R. (1995). Competition for electron donors among nitrate reducers, ferric iron reducers, sulfate reducers, and methanogens in anoxic paddy soils. Bio Fertil Soils 19: 65-72.

Aller RC. (1980). Diagenetic processes near the sedimentwater interface of Long Island Sound. II. Fe and Mn. Adv Geophys 22: 351-415.

Aller RC. (1990). Bioturbation and manganese cycling in hemipelagic sediments. Philos Trans $R$ Soc Lond $A$ 331: 51-68.

Bond DR, Holmes DE, Tender LM, Lovley DR. (2002). Electrode-reducing microorganisms that harvest energy from marine sediments. Science 295: 483-485.

Boone DR, Liu Y, Zhao Z-J, Balkwill DL, Drake GR, Stevens TO et al. (1995). Bacillus infernus sp. nov., an $\mathrm{Fe}(\mathrm{III})-$ and Mn(IV)-reducing anaerobe from the deep terrestrial subsurface. Int J Syst Bacteriol 45: 441-448.
Borin S, Brusetti L, Daffonchio D, Delaney E, Baldi F. (2009). Biodiversity of prokaryotic communities in sediments of different sub-basins of the Venice lagoon. Res Microbiol 160: 307-314.

Bowman JP, Gosink JJ, McCammon SA, Lewis TE, Nichols DS, Nichols PD et al. (1998). Colwellia demingiae sp. nov., Colwellia hornerae sp. nov., Colwellia rossensis sp. nov. and Colwellia psychrotropica sp. nov.: psychrophilic Antarctic species with the ability to synthesize docosahexaenoic acid (22: 63). Int J Syst Bacteriol 48: 1171-1180.

Bowman JP, McCammon SA, Brown MV, Nichols DS, McMeekin TA. (1997). Diversity and association of psychrophilic bacteria in Antarctic sea ice. Appl Environ Microbiol 63: 3068-3078.

Bowman JP, McCuaig RD. (2003). Biodiversity, community structural shifts, and biogeography of prokaryotes within Antarctic continental shelf sediments. Appl Environ Microbiol 69: 2463-2483.

Brown MV, Bowman JP. (2001). A molecular phylogenetic survey of sea-ice microbial communities (SIMCO). FEMS Microbiol Ecol 35: 267-275.

Burdige DJ, Nealson KH. (1985). Microbial manganese reduction by enrichment cultures from coastal marine sediments. Appl Environ Microbiol 50: 491-497.

Caccavo FJ, Blakemore RP, Lovley DR. (1992). A hydrogenoxidizing, Fe(III)-reducing microorganism from the Great Bay Estuary, New Hampshire. Appl Environ Microbiol 58: 3211-3216.

Campbell KM, Malasarn D, Saltikov CW, Newman DK, Hering JG. (2006). Simultaneous microbial reduction of iron(III) and arsenic(V) in suspensions of hydrous ferric oxide. Environ Sci Technol 40: 5950-5955.

Canfield DE, Jørgensen BB, Fossing H, Glud R, Gundersen J, Ramsing NB et al. (1993a). Pathways of organic carbon oxidation in three continental margin sediments. Mar Geol 113: 27-40.

Canfield DE, Thamdrup B, Hansen JW. (1993b). The anaerobic degradation of organic matter in Danish coastal sediments: Iron reduction, manganese reduction, and sulfate reduction. Geochim Cosmochim Acta 57: 3857-3883.

Chang Y-J, Long PE, Geyer R, Peacock AD, Resch CT, Sublette K et al. (2005). Microbial incorporation of ${ }^{13} \mathrm{C}-$ labeled acetate at the field scale: detection of microbes responsible for reduction of U(VI). Environ Sci Technol 39: 9039-9048.

DeLong EF, Franks DG, Alldredge AL. (1993). Phylogenetic diversity of aggregate-attached vs. free-living marine bacterial assemblages. Limnol Oceanogr 38: 924-934.

Deming JW, Somers LK, Straube WL, Swartz DG, MacDonell MT. (1988). Isolation of an obligately barophilic bacterium and description of a new genus, Colwellia gen. nov. Syst Appl Microbiol 10: 152-160.

Engström P, Dalsgaard T, Hulth S, Aller RC. (2005). Anaerobic ammonium oxidation by nitrite (anammox): Implications for $\mathrm{N}_{2}$ production in coastal marine sediments. Geochim Cosmochim Acta 69: 2057-2065.

Fedorovich V, Knighton MC, Pagaling E, Ward FB, Free A, Goryanin I. (2009). Novel electrochemically active bacterium phylogenetically related to Arcobacter butzleri, isolated from a microbial fuel cell. Appl Environ Microbiol 75: 7326-7334.

Finke N, Vandieken V, Jørgensen BB. (2007). Acetate, lactate, propionate, and isobutyrate as electron donors 
for iron and sulfate reduction in Arctic marine sediments, Svalbard. FEMS Microbiol Ecol 59: 10-22.

Freese E, Sass H, Rütters H, Schledjewski R, Rullkötter J. (2008). Variable temperature-related changes in fatty acid composition of bacterial isolates from German Wadden sea sediments representing different bacterial phyla. Org Geochem 39: 1427-1438.

Fukui M, Suh J, Yonezawa Y, Urushigawa Y. (1997). Major substrates for microbial sulfate reduction in the sediments of Ise Bay, Japan. Ecol Res 12: 201-209.

Goldberg T, Archer C, Vance D, Thamdrup B, McAnena A, Poulton SW. (2012). Controls on Mo isotope fractionations in a Mn-rich anoxic marine sediment, Gullmar Fjord, Sweden. Chem Geol 296-297: 73-82.

Gosink JJ, Staley JT. (1995). Biodiversity of gas vacuolate bacteria from Antarctic sea ice and water. Appl Environ Microbiol 61: 3486-3489.

Hedlund BP, Geiselbrecht AD, Bair TJ, Staley JT. (1999). Polycyclic aromatic hydrocarbon degradation by a new marine bacterium, Neptunomonas naphthovorans gen. nov., sp. nov. Appl Environ Microbiol 65: 251-259.

Heuer V, Pohlman JW, Torres ME, Elvert M, Hinrichs K-U. (2009). The stable carbon isotope biogeochemistry of acetate and other dissolved carbon species in deep subseafloor sediments at the northern Cascadia Margin. Geochim Cosmochim Acta 73: 3323-3336.

Holmes DE, Finneran KT, O’Neil RA, Lovley DR. (2002). Enrichment of members of the family Geobacteraceae associated with stimulation of dissimilatory metal reduction in uranium-contaminated aquifer sediments. Appl Environ Microbiol 68: 2300-2306.

Holmes DE, Nicoll JS, Bond DR, Lovley DR. (2004). Potential role of a novel psychrotolerant member of the family Geobacteraceae, Geopsychrobacter electrodiphilus gen. nov., sp. nov., in electricity production by a marine sediment fuel cell. Appl Environ Microbiol 70: 6023-6030.

Hori T, Müller A, Igarashi Y, Conrad R, Friedrich MW. (2010). Identification of iron-reducing microorganisms in anoxic rice paddy soil by ${ }^{13} \mathrm{C}$-acetate probing. ISME J 4: 267-278.

Hyun J-H, Mok J-S, You O-R, Kim D, Choi D-L. (2010). Variations and controls of sulfate reduction in the continental slope and rise of the Ulleung Basin off the Southeast Korean upwelling system in the East Sea. Geomicrobiol J 27: 212-222.

Jung S-Y, Oh T-K, Yoon J-H. (2006). Colwellia aestuarii sp. nov., isolated from a tidal flat sediment in Korea. Int $J$ Syst Evol Microbiol 56: 33-37.

Koskinen K, Hultman J, Auvinen P, Kankaanpää H. (2011). Spatially differing bacterial communities in water columns of the northern Baltic Sea. FEMS Microbiol Ecol 75: 99-110.

Kunapuli U, Lueders T, Meckenstock RU. (2007). The use of stable isotope probing to identify key iron-reducing microorganisms involved in anaerobic benzene degradation. ISMEJ 1: 643-653.

Lavik G, Stührmann T, Brüchert V, Van der Plas A, Mohrholz V, Lam P et al. (2009). Detoxification of sulphidic African shelf waters by blooming chemolithotrophs. Nature 457: 581-584.

Lin X, Wakeham SG, Putnam IF, Astor YM, Scranton MI, Chistoserdov AY et al. (2006). Comparison of vertical distributions of prokaryotic assemblages in the anoxic Cariaco Basin and Black Sea by use of fluorescence in situ hybridization. Appl Environ Microbiol 72: 2679-2690.
Llobet-Brossa E, Rosselló-Mora R, Amann R. (1998). Microbial community composition of Wadden Sea sediments as revealed by fluorescence in situ hybridization. Appl Environ Microbiol 64: 2691-2696.

Lovley DR, Goodwin S. (1988). Hydrogen concentrations as an indicator of the predominant terminal electronaccepting reactions in aquatic sediments. Geochim Cosmochim Acta 52: 2993-3003.

Lovley DR, Holmes DE, Nevin KP. (2004). Dissimilatory Fe(III) and Mn(IV) reduction. Adv Microb Physiol 49: 219-285.

Lueders T, Manefield M, Friedrich MW. (2004). Enhanced sensitivity of DNA- and rRNA-based stable isotope probing by fractionation and quantitative analysis of isopycnic centrifugation gradients. Environ Microbiol 6: 73-78.

Madrid VM, Taylor GT, Scranton MI, Chistoserdov AY. (2001). Phylogenetic diversity of bacterial and archaeal communities in the anoxic zone of the Cariaco Basin. Appl Environ Microbiol 67: 1663-1674.

Mußmann M, Ishii K, Rabus R, Amann R. (2005). Diversity and vertical distribution of cultured and uncultured Deltaproteobacteria in an intertidal mud flat of the Wadden Sea. Environ Microbiol 7: 405-418.

Myers CR, Nealson KH. (1988). Bacterial manganese reduction and growth with manganese oxide as the sole electron acceptor. Science 240: 1319-1321.

Nakagawa T, Iino T, Suzuki K, Harayama S. (2006). Ferrimonas futtsuensis sp. nov. and Ferrimonas kyonanensis sp. nov., selenate-reducing bacteria belonging to the Gammaproteobacteria isolated from Tokyo Bay. Int J Syst Evol Microbiol 56: 2639-2645.

Nealson KH, Myers CR, Wimpee BB. (1991). Isolation and identification of manganese-reducing bacteria and estimates of microbial Mn(IV)-reducing potential in the Black Sea. Deep-Sea Res 38: S907-S920.

Nickel M, Vandieken V, Brüchert V, Jørgensen BB. (2008). Microbial $\mathrm{Mn}(\mathrm{IV})$ and $\mathrm{Fe}(\mathrm{III})$ reduction in northern Barents Sea sediments under different conditions of ice cover and organic carbon deposition. Deep-Sea Res II 55: 2390-2398.

Nogi Y, Hosoya S, Kato C, Horikoshi K. (2004). Colwellia piezophila sp. nov., a novel piezophilic species from deep-sea sediments of the Japan Trench. Int J Syst Evol Microbiol 54: 1627-1631.

Osaka T, Yoshie S, Tsuneda S, Hirata A, Iwami N, Inamori Y. (2006). Identification of acetate- or methanolassimilating bacteria under nitrate-reducing conditions by stable-isotope probing. Microb Ecol 52: 253-266.

Parkes RJ, Gibson GR, Mueller-Harvey I, Buckingham WJ, Herbert RA. (1989). Determination of the substrates for sulphate-reducing bacteria within marine and estuarine sediments with different rates of sulphate reduction. J Gen Microbiol 135: 175-187.

Pester M, Loy A. (2010). Probing identity and physiology of uncultured microorganisms with isotopic labeling techniques. In: Barton L, Mandl M, Loy A (eds) Geomicrobiology: Molecular and Environmental Perspective. Springer: Heidelberg, pp 127-146.

Pilloni G, von Netzer F, Engel M, Lueders T. (2011). Electron acceptor-dependent identification of key anaerobic toluene degraders at a tar-oil contaminated aquifer by Pyro-SIP. FEMS Microbiol Ecol 78: 165-175.

Ravenschlag K, Sahm K, Pernthaler J, Amann R. (1999). High bacterial diversity in permanently cold marine sediments. Appl Environ Microbiol 65: 3982-3989. 
Rosselló-Mora R, Ludwig W, Kämpfer P, Amann R, Schleifer KH. (1995). Ferrimonas balerica gen. nov., sp. nov., a new marine facultative Fe(III)-reducing bacterium. Syst Appl Microbiol 18: 196-202.

Sansone FJ, Martens CS. (1982). Volatile fatty acid cycling in organic-rich marine sediments. Geochim Cosmochim Acta 46: 1575-1589.

Schmidtova J, Hallam SJ, Baldwin SA. (2009). Phylogenetic diversity of transition and anoxic zone bacterial communities within a near-shore anoxic basin: Nitinat Lake. Environ Microbiol 11: 3233-3251.

Snoeyenbos-West OL, Nevin KP, Anderson RT, Lovley DR. (2000). Enrichment of Geobacter species in response to stimulation of $\mathrm{Fe}(\mathrm{III})$ reduction in sandy aquifer sediments. Microb Ecol 39: 153-167.

Sørensen J, Christensen D, Jørgensen BB. (1981). Volatile fatty acids and hydrogen as substrates for sulfatereducing bacteria in anaerobic marine sediment. Appl Environ Microbiol 42: 5-11.

Sundby B, Silverberg N, Chesselet R. (1981). Pathways of manganese in an open estuarine system. Geochim Cosmochim Acta 45: 293-307.

Thamdrup B. (2000). Bacterial manganese and iron reduction in aquatic sediments. Adv Microb Ecol 16: 41-84.

Thamdrup B, Canfield CE. (1996). Pathways of carbon oxidation in continental margin sediments off central Chile. Limnol Oceanogr 41: 1629-1650.

Thamdrup B, Dalsgaard T. (2000). The fate of ammonium in anoxic manganese oxide-rich marine sediment. Geochim Cosmochim Acta 64: 4157-4164.

Thamdrup B, Glud R, Hansen JW. (1994). Manganese oxidation and in situ manganese fluxes from a coastal sediment. Geochim Cosmochim Acta 58: 2563-2570.

Thamdrup B, Rosselló-Mora R, Amann R. (2000). Microbial manganese and sulfate reduction in Black Sea shelf sediments. Appl Environ Microbiol 66: 2888-2897.
Vandieken V, Finke N, Jørgensen BB. (2006a). Pathways of carbon oxidation in an Arctic fjord sediment (Svalbard) and isolation of psychrophilic and psychrotolerant Fe(III)-reducing bacteria. Mar Ecol Prog Ser 322: 29-41.

Vandieken V, Nickel M, Jørgensen BB. (2006b). Carbon mineralization in Arctic sediments northeast of Svalbard: $\mathrm{Mn}(\mathrm{IV})$ and $\mathrm{Fe}(\mathrm{III})$ reduction as principal anaerobic respiratory pathways. Mar Ecol Prog Ser 322: 15-27.

Venkateswaran D, Dollhopf ME, Aller R, Stackebrandt E, Nealson KH. (1998). Shewanella amazonensis sp. nov., a novel metal-reducing facultative anaerobe from Amazonian shelf muds. Int J Syst Bacteriol 48: 965-972.

Vetriani C, Tran HV, Kerkhof LJ. (2003). Fingerprinting microbial assemblages from the oxic/anoxic chemocline of the Black Sea. Appl Environ Microbiol 69: 6481-6488.

Webster G, Rinna J, Roussel EG, Fry JC, Weightman AJ, Parkes RJ. (2010). Prokaryotic functional diversity in different biogeochemical depth zones in tidal sediments of the Severn Estuary, UK, revealed by stableisotope probing. FEMS Microbiol Ecol 72: 179-197.

Wellsbury P, Mather I, Parkes RJ. (2002). Geomicrobiology of deep, low organic carbon sediments in the Woodlark Basin, Pacific Ocean. FEMS Microbiol Ecol 42: 59-70.

Whiteley AS, Manefield M, Lueders T. (2006). Unlocking the 'microbial black box' using RNA-based stable isotope probing technologies. Curr Opin Biotechnol 17: $67-71$.

Whiteley AS, Thomson B, Lueders T, Manefield M. (2007). RNA stable-isotope probing. Nat Protocols 2: 838-844.

Yumoto I, Kawasaki K, Iwata H, Matsuyama H, Okuyama H. (1998). Assignment of Vibrio sp. strain ABE-1 to Colwellia maris sp. nov., a new psychrophilic bacterium. Int J Syst Bacteriol 48: 1357-1362.

Supplementary Information accompanies the paper on The ISME Journal website (http://www.nature.com/ismej) 